\title{
Status of freshwater bodies from Ajara tahsil of Kolhapur district (MS), India with special reference to morphometric characteristics
}

\author{
Sachinkumar R. Patil*, S. S. Patil** and T. V. Sathe \\ *Department of Zoology, R. B. M. Mahavidhyalay, Chandgad, Dist.: Kolhapur (MS) India. \\ ** Post graduate center for Zoology, Krishna Mahavidhyalaya, Rethare (BK), Dist.: Satara (MS) India \\ Department of Zoology, Shivaji University, Kolhapur (MS) India
}

\begin{abstract}
The present attempt has been made to study the status of freshwater bodies from Ajara tahsil of Kolhapur District, Maharashtra, India by using Global Positioning System (GPS) with reference to survey and mapping. The investigation mainly focused on survey, location, mapping and submergence area of wetlands from this Tahsil. The results obtained from the study has compared with secondary data made available from Government authorities so as to reveal the percentage of change in the total submergence area of wetlands due to anthropogenic activities and other environmental factors. The study adds multi-temporal GPS information on the water bodies, which have prime importance to indicate environmental changes and anthropogenic activities. The present results indicate that 30 water bodies located in this tahsil, among which 5 are seasonal ponds while remaining are perennial water bodies. Total wetland area of tahsil is about $483.77 \mathrm{ha}$. The actual submergence area of Yarandol freshwater body was noted highest while lowest submergence was noted for Dabil pond. Since, emphasis is given on comparative morphometric features of 6 minor irrigation tanks and 1 percolation water body. The comparative study revealed that the submergence area of all reservoirs got increased except Ningudage water body, it might be due to anthropogenic activity.
\end{abstract}

Keywords:Freshwater body, morphometric features, GPS, anthropogenic activity, submergence area.

\section{Introduction}

India, by virtue of its geographical extent, varied terrain and climatic conditions, supports a rich diversity of inland and coastal wetland ecosystems. The wetlands in India are distributed in various ecological regions. Although the significance of wetlands has been known for a long time, their role in maintaining ecological balance is less understood. The Ramsar Convention of IUCN held during 1971 in Iran raised global awareness of the conservation and management of wetlands (Chopra et al., 2001).

Wetlands are providing ecological as well as economic services to the entire world since the ancient time and consequently, leading to unseen modifications. However, these are under the stress and need special attention. According to Hammer (2002), wetland habitats are threatened throughout the world. Various anthropological activities are leading wetland systems fragile. Many of the workers have carried out hydrological, Limnological and hydro-biological studies at various freshwater reservoirs at different places. Nevertheless, study of morphometric features were not in the limelight as these characters gives an idea about the status of a freshwater body with regard to geological control over their origin, development and characteristics. These features are helpful in building management strategies achieving the conservation aspect. Hence, priorityisgiven to create accurate and timely data about changing pattern of these wetlands. Monitoring wetland landscape change is the basis of almost any resource management planning or regional policy program (Guofu and Shengyu, 2004).

As wetlands are poorly documented features of many landscapes, and there is often little understanding of the geological controls on their origin, development and characteristics. They possess a diverse range of geological and sedimentary features that defy simple definition, characterization and classification (Scott and Jones, 1995). Global Positioning System (GPS) offers an ideal tool for the mapping and monitoring of such areas particularly as a mean of updating conventional data gathering techniques (Nellis, 1986). Some of researchers have worked on the mapping and survey so as to produce status of wetlands by using various methods like remote sensing (Sharafat Ali et al., 1991; Khorram and Cheshire, 1985), high resolution space photography (Pariharet al., 1986), landsat imagery method (Lindellet al., 1985), spectral reflectance data (Manu and Robertson, 1990) etc. For the need of proper documentary, GPS is also an ideal tool as it gives idea about location i. e. high degree accuracy for locating, mapping and estimating the total submergence area. Since the data is scanty on mapping of wetland, the technique of GPS has been standardized for surveying, mapping and estimating area (Sawantet al., 2014). Hence, present study is carried out to provide status of wetlands with reference to morphometric features as the baseline data is not available at tahsil level. 


\section{a. Study area:}

\section{Materials And Methods}

Ajara is one of the important tahsil of Kolhapur district, located at southern region with $\mathrm{N} 16^{0} 12^{\prime}$ and E $74^{0} 2^{\prime}$. Total population of the tahsil is about $1,21,430$ residing in 74 villages. The total area of the tahsil is about 54,853 ha. Geographically, the area is undulating throughout the tahsil except some part of its northwestern region. The climate is moderate subtropical with an average annual rainfall of $2000 \mathrm{~mm}$. Ajara is famous for its natural landscape, since most of the area is covered with forest and falls under corridor of Western Ghats and Konkan. The people residing here depend on two important rivers for their domestic, agricultural and drinking water needs viz. Hiranyakeshi River and Chitri River. However, Chitri River runs a very short course and joins Hiranyakeshi River just 8-9 km from its birthplace. The River Hiranyakeshi flows throughout the year as a Dam is constructed on Chitri. On the other hand, villages away from these rivers depend on bore-wells, dug-wells, small and large freshwater reservoirs for their daily use. Along with socioeconomic importance, these freshwater reservoirs have ecological importance as supports many biological entities. Hence, present study was conducted in the context of survey and mapping to estimate wetland area of the tahsil.

\section{b. Survey and mapping:}

\section{i. Field Survey and mapping:}

Frequent visits were made to locate the water bodies of Gadhinglaj Tahsil. After preliminary survey, water bodies were identified and classified and accordingly, ecological observations were noted for individual water bodies and mapping of major water bodies was made. Mapping of all major water bodies were carried out by selecting two co-ordinates at each water body individually by using hand held Global Positioning System (GARMIN eTREX vista $\mathrm{HCx}$ ) and walking along the perimeter of water reservoir twice a year viz. immediate after monsoon season and at the end of summer season so as to obtain temporal area of water reservoirs.

\section{ii. Application of Computer:}

The obtained field data is analyzed by using computer software MapSource while using different tools from this software, further location and actual submergence area is calculated. Then the primary data is compared with secondary data which is made available from Irrigation Department, Gadhinglaj and ZilhaParishad of Ajara tahsil.

\section{Result And Discussion}

The preliminary survey was conducted and it has been revealed that 30 small and large freshwater reservoirs might be mainly classified into four categories viz. medium irrigation reservoir, minor irrigation reservoir, percolation pond and small seasonal pond. Few of them are seasonal whereas the remaining are perennial. Among 30 freshwater reservoirs, seven perennial reservoirs were selected for the present study based on area and age of the reservoir.

Table I to Table IV represents the morphometric features along with actual submergence area of 30 freshwater reservoirs from Ajara tahsil while Figure 1 to Figure12 represents the GPS maps and Google maps of selected water reservoirs of Ajara tahsil. The present study is discussed in context of morphometric changes that occurred in seven freshwater reservoirs, selected for the study.

Gavase freshwater reservoir (Figure 1 and 2) is situated south-west to the Ajara city at N $16^{0} 05^{\prime} 761^{\prime \prime}$ and E 7407'596". The reservoir was man-made and construction of the dam was completed in the year 2003. The storage capacity of the reservoir is about 1.15 cuM.along with dam height and length of $23.87 \mathrm{~m}$ and $29.5 \mathrm{~m}$ respectively. The catchment area is about $2.85 \mathrm{~km}$. According to government records, the total submergence area of the reservoir is 15.2 ha while the actual submergence area estimated during the study is 37.04 ha during monsoon season and 3.79 ha during summer season. It indicates that the total submergence area has increased at present than in the past. This might be due to natural processes like weathering, land sliding etc. On the other hand, submergence area was decreased during summer season and it might be due to evaporation and release of water from reservoir to downstream.

Dhangarmola freshwater reservoir (Figure 3 and 4) is situated at south-west to the Ajara city with longitude and latitude of $16^{\circ} 03^{\prime} 687^{\prime \prime}$ and $74^{\circ} 05^{\prime} 647^{\prime}$ '. The dam was constructed in the year 2000 . The height and length of the dam is about $19.28 \mathrm{~m}$ and $510 \mathrm{~m}$ respectively. The total catchment area is about $8.6 \mathrm{~km}$. The total submergence area of the reservoir with respect to government records is 41.09 ha and actual submergence area mapped by GPS is 55.17 ha. The submergence area mapped during summer season is 7.32 ha. The present investigation showed that the submergence area of this reservoir is increased as compared to government records which might be due to land sliding and weathering. The submergence area of reservoir was shrink during summer season might be due to release of water downstream. 
The location of Yarandol freshwater body (Figure 5 and 6) is N $16^{\circ} 03^{\prime} 629^{\prime \prime}$ and E $74^{\circ} 10^{\prime} 539^{\prime \prime}$, situated to the south of Ajara city. This reservoir was constructed in the year 1998. The catchment area of this reservoir is about $15.2 \mathrm{~km}$. The height of the dam is about $30.85 \mathrm{~m}$ and length is about $475 \mathrm{~m}$. The total submergence area of the reservoir when constructed was 65.95 ha. On the other hand, submergence area at present is 71.48 ha during monsoon season. It might be due to anthropological activities such as mining of soil and leveling of land. The soil is used for the purpose of house construction and preparation of bricks, while leveling is made for farming in the months of summer. The total submergence area got reduced to 36.52 ha during summer season which might be due to lifting of water from the reservoir for irrigation purpose, since 49 irrigation pumps were noted during the survey.

Khanapur freshwater reservoir (Figure 7 and 8) was constructed in the year 1995 which is situated at south-west of Ajara city with the location of $\mathrm{N} 16^{\circ} 05^{\prime} 352^{\prime \prime}$ and E $74^{\circ} 18^{\prime} 132^{\prime \prime}$. The length of the dam is $220 \mathrm{~m}$ and height of the dam is $21.15 \mathrm{~m}$. The total storage capacity is $0.8 \mathrm{cuM}$. The catchment area of the reservoir is $1.81 \mathrm{~km}$. Total submergence area of the reservoir according to secondary data is 16.7 ha while actual mapped submergence area is $20.71 \mathrm{ha}$. The increase in the submergence area is not significant. The submergence area of the reservoir during summer season was 3.13 ha. The shrinkage of water level during summer season might be due to release of water downstream for irrigation purpose.

Ningudage freshwater body (Figure 9 and 10) is situated at north-east of the Ajara city with the location of $\mathrm{N} 16^{\circ} 09^{\prime} 325^{\prime \prime}$ and $\mathrm{E} 74^{\circ} 18^{\prime} 132$ ". The reservoir was constructed in the year 1982. The storage capacity of the reservoir is $0.12 \mathrm{cuM}$. Total catchment area is $0.23 \mathrm{~km}$ with the submergence area of 9 ha with reference to government records. However, GPS mapping showed that the actual submergence area is 4.28 ha. This is the only freshwater body that exhibited reduction in submergence area among all. It might be due to anthropological activities. During the study period highest anthropological activities were noted at the reservoir as compared to others. The reservoir is occupied by vegetation and algal bloom that might be the reason for the reduction of submergence area. The submergence area during summer season was 2.35 ha.

The geographical location of Ghatkarwadi reservoir (Figure 11 and 12) is N $16^{\circ} 02^{\prime} 510^{\prime \prime}$ and E $74^{\circ} 04^{\prime}$ $055^{\prime \prime}$ and it is situated south-west to Ajara city. This reservoir was constructed in the year 2007. The total submergence are during monsoon season is about 38.33 ha while it was noted 8.89 ha during summer season. The submergence area with reference to secondary data is about 19.64 ha which is increased in actual GPS mapping by about 20 ha. Increase in the actual submergence area might be due to natural processes like land sliding and weathering.

Maligre freshwater body (Figure 13 and 14) is situated N $16^{\circ} 07^{\prime} 352^{\prime \prime}$ and E $74^{\circ} 16^{\prime} 985^{\prime \prime}$ with total submergence area of 4.30 ha during monsoon season and 2.12 ha during summer season. The secondary data is not available for this reservoir.

The geographical location, actual submergence area, year of construction, ecological status and type water body for remaining freshwater bodies and ponds are given in Table II to Table IV. The secondary data is not available for these water bodies hence the comparison is not made. This data will emphasize the status of these water bodies for further utilization and policy making.

On global basis, it has been estimated that more than $50 \%$ of the wetlands have been degraded or destroyed by land use practices like overgrazing and over burning, by development processes e.g. drainage modification, land reclamation or by exotic invasive vegetation or feral of animals (Dugan, 1993). Urban, agricultural and water resources developments still threaten many wetlands, with other threats coming from the possible negative effects of global climate change on wetland structure and function (Winter, 2000).

\section{Conclusion}

The present study concludes that the submergence area of all reservoirs was increased except Ningudage, whose submergence area was shown to be decreased. During the study period, more anthropogenic activities were observed at Yarandol and Ningudage freshwater reservoirs but the effect of the phenomenon was contrary. However, the increase in submergence area at remaining reservoirs might be due to natural phenomenon, since anthropological activities were negligible at these sites.

\section{Acknowledgment}

Authors are thankful to Mr. Rahul S. Patil, Mr. Girish M. Patil and Mr. SatishPawar for their cooperation during field survey and mapping. Authors are also thankful of Officers from ZilhaParishad and Irrigation Department, Ajara for providing secondary data.

\section{References}

[1]. Chopra, R., V. K. Verma and P. K. Sharma (2001).Mapping, monitoring and conservation of Harike wetland ecosystem, Punjab, India through remote sensing.Int. J. Remote Sensing.22 (1): 89-98.

[2]. Dugan P. J. (1993). Editor wetlands in Danger.London: Mitchel Beazley and IUCN (World Conservation Union)

[3]. Hammer D. A. (1992). Creating freshwater wetlands.Boca Raton: Lewis Publishers. 
Status of freshwater bodies from Ajara tahsil of Kolhapur district (MS), India with special ....

[4]. Khorram, S. and Cheshire, H. M. (1985) Remote sensing of water quality in the Neuse river estuary, North Carolina.Journal of Photogrammetric Engineering and Remote Sensing, 51, 329-341.

[5]. LIANG Guofu and DING Shengyan (2004). Impacts of human activity and natural change on the wetland landscape pattern along the Yellow River in Henan Province. Journal of Geographical Sciences, 14 (3): 339-348.

[6]. Lindell, L. T., Steinvall, Johnson, O. M., and Classon, T. H. (1985).Mapping of coastal water turbidity using Landsat imagery.International Journal of Remote Sensing, 6, 629-642.

[7]. Manu, L., and Robertson, C., 1990, Estimating suspended sediment concentration from spectral reflectance data. International Journal of Remote Sensing, 11, 913-920.

[8]. Nellis M. (1986). Remote sensing for monitoring rangeland management strategies in the Kanas Flint Hills. Proceedings of the Symposium of Commission IV, 370-375.

[9]. Parihar, J. S., Kotwal, P. C., Panigrahi, S., and Chaturvedi, N. (1986). Study of wildlife habitat using high resolution space photographs. A case study of Kanha National Park. ISRO-SP-17-86, Special Publication of Indian Space Research Organisation, Space Applications Centre, Ahmedabad, pp. 65-82.

[10]. Rajaram S. Sawant, Niranjana S. Chavan and Sachinkumar R. Patil (2014).Survey and mapping of freshwater bodies from Gadhinglaj tahsil of Maharashtra (India) by using GPS. IOSR J. Environ. Sci. Toxicol. and Food Tech. 8 (8): 17-22.

[11]. Scott D. A. and Jones T. A. (1995).Classification and inventory of wetlands: a global review.Vegetatio, 118: 3-16.

[12]. Sharafat Ali, Saha, N. C., and SurajBhan, 1991, Wetland resources mapping in West Bengal using remotely sensed data. National Symposium on Remote Sensing of Environment, Madras, 10-12 December 1991 (Dehradun: Indian Society of Remote Sensing).

[13]. Winter A. C. (2000). The vulnerability of wetlands to climate change: a hydrological landscape perspective. J. the American Water Resources Association, 36: 305-311.

Table I: Morphometric features of selected freshwater bodies from Ajara tahsil

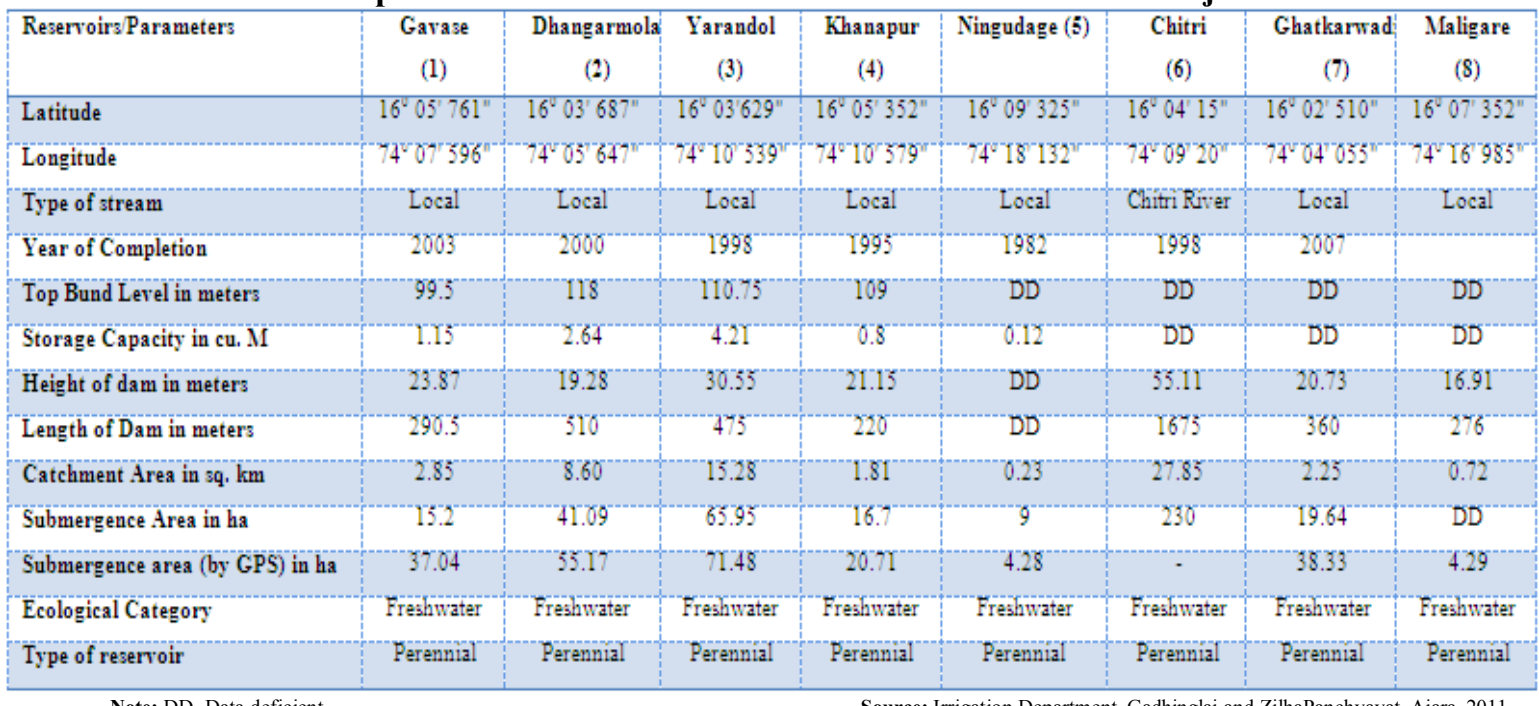

Note: DD- Data deficient

Source: Irrigation Department, Gadhinglaj and ZilhaPanchyayat, Ajara, 2011

Table II: Morphometric features of freshwater bodies from Ajara tahsil

\begin{tabular}{|c|c|c|c|c|c|c|c|}
\hline Reservoirs/Parameters & $\begin{array}{c}\text { Medhewadi } \\
\text { (9) }\end{array}$ & $\begin{array}{c}\text { Vajare } \\
(10)\end{array}$ & $\begin{array}{c}\text { Peranoli } \\
\text { (11) }\end{array}$ & $\begin{array}{c}\text { Dhangarmola_A } \\
\text { (12) }\end{array}$ & $\begin{array}{c}\text { Dhangarmola_B } \\
\text { (13) }\end{array}$ & $\begin{array}{c}\text { Dhangarmola_C } \\
\text { (14) }\end{array}$ & $\begin{array}{c}\text { Dhangarmola_D } \\
\text { (15) }\end{array}$ \\
\hline Latitude & $16^{\circ} 07^{\prime} 368^{\prime \prime}$ & $16^{\circ} 10950^{\prime \prime}$ & $16^{\circ} 09114^{\prime \prime}$ & $16^{\circ} 04^{\prime} 870^{\prime \prime}$ & $16^{\circ} 03^{\prime} 317^{\prime \prime}$ & $16^{\circ} 03^{\prime} 368^{\prime \prime}$ & $16^{\circ} 04^{\prime} 016^{\prime \prime}$ \\
\hline Longitude & $74^{0} 16952$ & $74^{\circ} \mathrm{YIO}^{2} \mathrm{4}^{\mathrm{n}}$ & $74^{4} 10029$ & $74^{0} 05^{7} 270^{n-1}$ & $74^{\circ} 04^{-78} 784^{r-}$ & $74^{\circ} 04917^{n-1}$ & $74^{0} 05648^{15}$ \\
\hline Type of stream & Local" & Local & Local & Local" & Local & 'Local' & Local \\
\hline Year of Completion & $\mathrm{DD}$ & $2000^{-1}$ & $\mathrm{DD}$ & $-1994^{-}$ & 1993 & $1993^{-1}$ & 2001 \\
\hline Top Bund Level in meters & $\mathrm{DD}^{-}$ & $\mathrm{DD}$ & $\mathrm{DD}^{--}$ & $\mathrm{DD}$ & $\mathrm{DD}^{-}$ & $\mathrm{DD}$ & $\mathrm{DD}$ \\
\hline Storage Capacity in cu. $\mathrm{M}$ & $\mathrm{DD}^{-}$ & $\mathrm{DD}^{--}$ & $\mathrm{DD}$ & $\mathrm{DD}$ & $\mathrm{DD}$ & $\mathrm{DD}$ & $\mathrm{DD}$ \\
\hline Height of dam in meters & 14 & $\mathrm{DD}$ & DD & $\mathrm{DD}$ & $\mathrm{DD}$ & $\mathrm{DD}$ & $\mathrm{DD}^{-}$ \\
\hline Length of Dam in meters & 135 & $\mathrm{DD}^{-}$ & $\mathrm{DD}$ & $\mathrm{DD}$ & $\mathrm{DD}$ & $\mathrm{DD}$ & $\mathrm{DD}$ \\
\hline Catchment Area in $3 q . \mathrm{km}$ & 0.7 & $\mathrm{DD}$ & $\mathrm{DD}^{-}$ & $\mathrm{DD}$ & $\mathrm{DD}$ & $\mathrm{DD}^{-}$ & $\mathrm{DD}^{-}$ \\
\hline Submergence Area in ha & $\mathrm{DD}$ & $\mathrm{DD}$ & $\mathrm{DD}$ & $\mathrm{DD}$ & $\mathrm{DD}$ & $\mathrm{DD}$ & $\mathrm{DD}$ \\
\hline Submergence area (by GPS) in ha & $2.93^{---}$ & 1.43 & 0.36 & 1.47 & 0.17 & $\mathrm{NA}^{-}$ & 0.53 \\
\hline Ecological Category & Freshwater & Freshwater & Freshwater & Freshwater & Freshwater & Freshwater & Freshwater \\
\hline Type of reservoir & Perennial" & Perennial & Perennial" & Perennial"- & Perennial" & Perennial"- & Perennial" \\
\hline
\end{tabular}

Note: DD- Data deficient, NA- Not accessible

Source: Irrigation Department, Gadhinglaj and ZilhaPanchyayat, Ajara, 2011 
Table III: Morphometric features of freshwater bodies from Ajara tahsil

\begin{tabular}{|c|c|c|c|c|c|c|c|c|}
\hline Reservoirs/Parameters & $\begin{array}{c}\text { Kitawade_A } \\
\text { (16) }\end{array}$ & $\begin{array}{c}\text { Kitawade_B } \\
\text { (17) }\end{array}$ & $\begin{array}{c}\text { Shringarwadi } \\
\text { (18) }\end{array}$ & $\begin{array}{c}\text { Honewadi } \\
\text { (19) }\end{array}$ & $\begin{array}{c}\text { Bhadwan } \\
\text { (20) }\end{array}$ & $\begin{array}{l}\text { Vatangi } \\
\text { (21) }\end{array}$ & $\begin{array}{c}\text { Bhadwanwadi } \\
\text { (22) }\end{array}$ & $\begin{array}{l}\text { Dabil } \\
\text { (23) }\end{array}$ \\
\hline Latitude & $16^{\circ} 02^{\prime} 834^{\prime \prime}$ & $16^{\circ} 02^{\prime} 906^{\prime \prime}$ & $16^{\circ} 05^{\prime} 054^{\prime \prime}$ & $16^{\circ} 07162^{\prime \prime}$ & $16^{\circ} 09603^{\prime \prime}$ & $16^{\circ} 03566^{\prime \prime}$ & $16^{\circ} 10^{\prime} 039^{\prime \prime}$ & $16^{\circ} 07673^{\prime \prime}$ \\
\hline Longitude & $74^{\circ} 02681^{1-}$ & $74^{0} 02635^{n-1}$ & $74^{\circ} 14025^{n-1}$ & $74^{0} 15202^{12}$ & $74^{\circ} 13^{2} 613^{n^{-}}$ & $74 \div 166^{2}$ & 74.16316 & $74^{0} 05925^{1-}$ \\
\hline Type of stream & Local & tocal & Local" & Local" & Local & Local & tocal & Local \\
\hline Year of Completion & $2013^{-1}$ & 2013 & 2001 & $\mathrm{DD}$ & $\mathrm{DD}$ & 2009 & 1995 & 2009 \\
\hline Top Bund Level in meters & $\mathrm{DD}^{-1}$ & $\mathrm{DD}$ & $\mathrm{DD}$ & $\mathrm{DD}^{-1}$ & $\mathrm{DD}$ & 3 & $\mathrm{DD}$ & $\mathrm{DD}^{--}$ \\
\hline Storage Capacity in cu. M & $\mathrm{DD}$ & $\mathrm{DD}$ & $\mathrm{DD}$ & $\mathrm{DD}^{-}$ & $\mathrm{DD}$ & 5.47 & $\mathrm{DD}$ & $\mathrm{DD}$ \\
\hline Height of dam in meters & DD & $\mathrm{DD}$ & 19.76 & $\mathrm{DD}^{-}$ & $\mathrm{DD}^{-1}$ & 13.9 & $\mathrm{DD}$ & $\mathrm{DD}^{-}$ \\
\hline Length of Dam in meters & $\mathrm{DD}^{-}$ & $\mathrm{DD}$ & $195^{-1}$ & DD & $\mathrm{DD}$ & 115 & $\mathrm{DD}$ & $\mathrm{DD}^{-}$ \\
\hline Catchment Area in sq. km & $\mathrm{DD}^{-1}$ & $\mathrm{DD}^{-1}$ & $0.88^{--1}$ & 0.25 & 0.18 & 1.97 & 0.69 & 0.47 \\
\hline Submergence Area in ha & $\mathrm{DD}^{-}$ & $\mathrm{DD}$ & $\mathrm{DD}^{-1}$ & $\mathrm{DD}^{-}$ & $\mathrm{DD}^{-}$ & 3.24 & $\mathrm{DD}^{--}$ & $\mathrm{DD}$ \\
\hline Submergence area (by GPS) in ha & $\mathrm{NC}^{-}$ & $\mathrm{NC}^{-}$ & 3.65 & 0.16 & $0.33^{-}$ & 1.98 & 0.56 & 0.11 \\
\hline Ecological Category & Freshwater & Freshwater & Freshwater & Freshwater & Freshwater & Freshwater & Freshwater & Freshwater \\
\hline Type of reservoir & 'Seasonal' & Seasonal" & Perennial' & Seasonal & Perennial' & Perennial" & Perennial' & Seasonal \\
\hline
\end{tabular}

Table IV: Morphometric features of freshwater bodies from Ajara tahsil

\begin{tabular}{|c|c|c|c|c|c|c|c|}
\hline Reservoirs/Parameters & $\begin{array}{l}\text { Uttur } \\
(24)\end{array}$ & $\begin{array}{l}\text { Bahirewadi } \\
\text { (25) }\end{array}$ & $\begin{array}{l}\text { Mumewadi } \\
\text { (26) }\end{array}$ & $\begin{array}{c}\text { Vadaksiwali } \\
\text { (27) }\end{array}$ & $\begin{array}{c}\text { Velavatti } \\
\text { (28) }\end{array}$ & $\begin{array}{c}\text { Gajargaon } \\
\text { (29) }\end{array}$ & $\begin{array}{c}\text { Sohalewadi } \\
\text { (30) }\end{array}$ \\
\hline Latitude & $16^{0} 14^{\prime} 597^{\prime \prime}$ & $16^{0} 16^{\prime} 672^{\prime \prime}$ & $16^{0} 15^{\prime} 133^{\prime \prime}$ & $16^{0} 11^{\prime} 566^{\prime \prime}$ & $16^{0} 06^{\prime} 807^{\prime \prime}$ & $16^{0} 13^{\prime} 130^{\prime \prime}$ & $16^{0} 09^{\prime} 116^{\prime \prime}$ \\
\hline Longitude & $74^{0} 15^{\prime} 633^{\prime \prime}$ & $74^{0} 18^{\prime} 778^{\prime \prime}$ & $74^{0} 17^{\prime} 295^{\prime \prime}$ & $74^{0} 12^{\prime} 888^{\prime \prime}$ & $74^{0} 09^{\prime} 818^{\prime \prime}$ & $74^{0} 21^{\prime} 010^{\prime \prime}$ & $74^{0} 11^{\prime} 630^{\prime \prime}$ \\
\hline Type of stream & Local & Local & Local & Local & Local & Local & Local \\
\hline Year of Completion & 2003 & 2000 & 2000 & 2000 & 2013 & DD & DD \\
\hline Storage Capacity in cu. $M$ & DD & $\mathrm{DD}$ & $\mathrm{DD}$ & $\mathrm{DD}$ & DD & 0.02 & $\mathrm{DD}$ \\
\hline Height of dam in meters & $\mathrm{DD}$ & $\mathrm{DD}$ & $\mathrm{DD}$ & DD & 18.66 & DD & DD \\
\hline Length of Dam in meters & DD & DD & $\mathrm{DD}$ & $\mathrm{DD}$ & 200 & DD & DD \\
\hline Catchment Area in sq. km & $\mathrm{DD}$ & DD & $\mathrm{DD}$ & 0.36 & 1.35 & 0.23 & 0.12 \\
\hline Type of reservoir & Perennial & Perennial & Perennial & Perennial & Perennial & Perennial & Seasonal \\
\hline
\end{tabular}

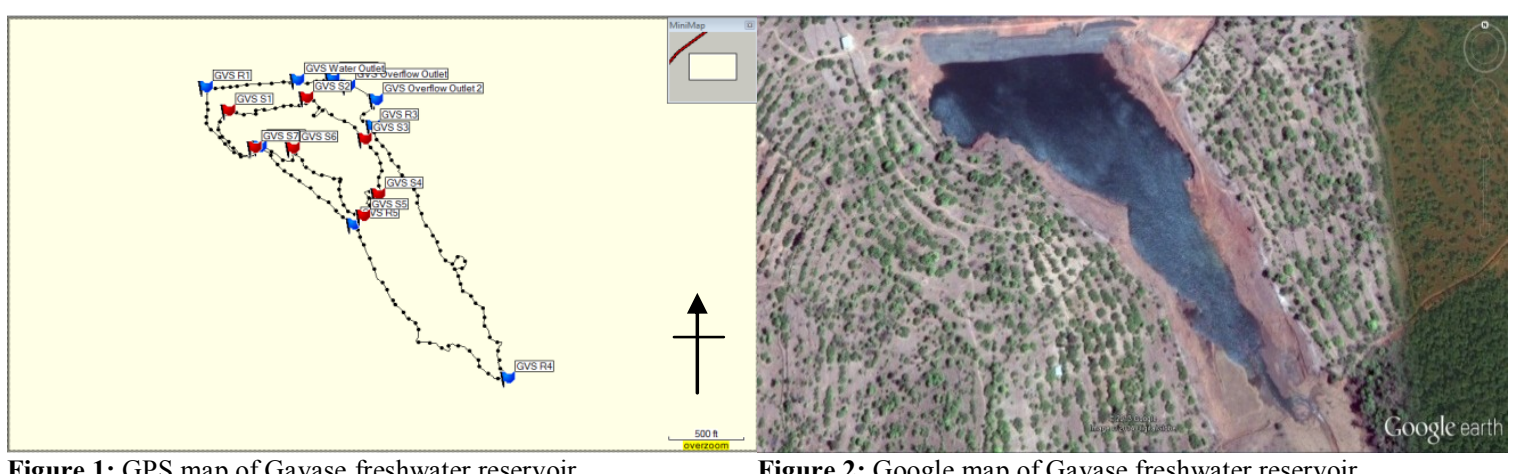

Figure 1: GPS map of Gavase freshwater reservoir

Figure 2: Google map of Gavase freshwater reservoir 
Status of freshwater bodies from Ajara tahsil of Kolhapur district (MS), India with special ....

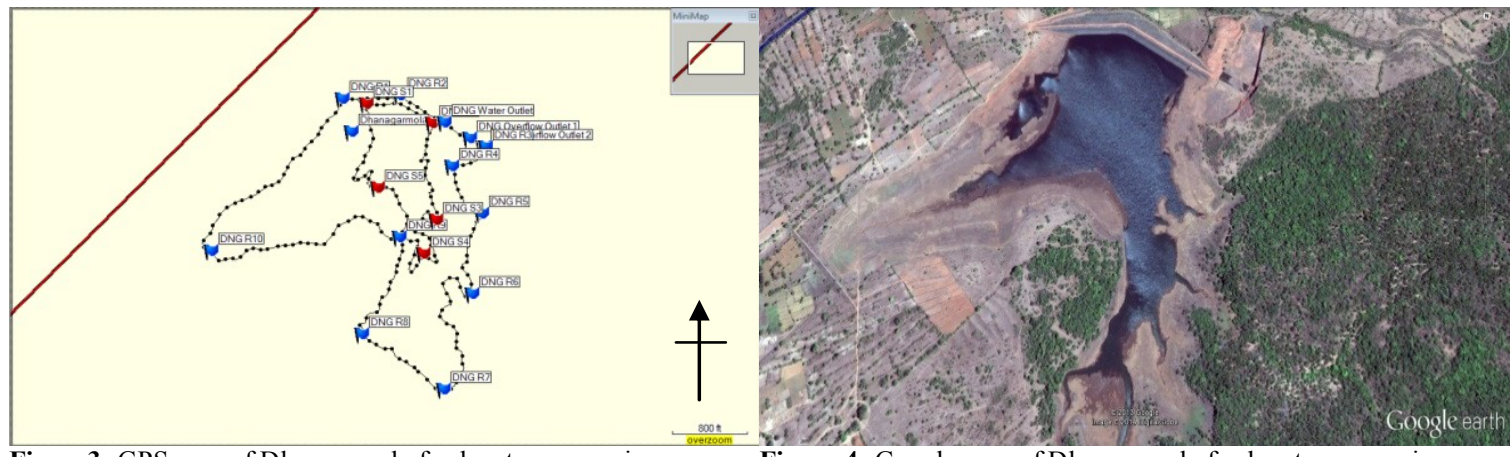

Figure3: GPS map of Dhangarmola freshwater reservoir

Figure 4: Google map of Dhangarmola freshwater reservoir

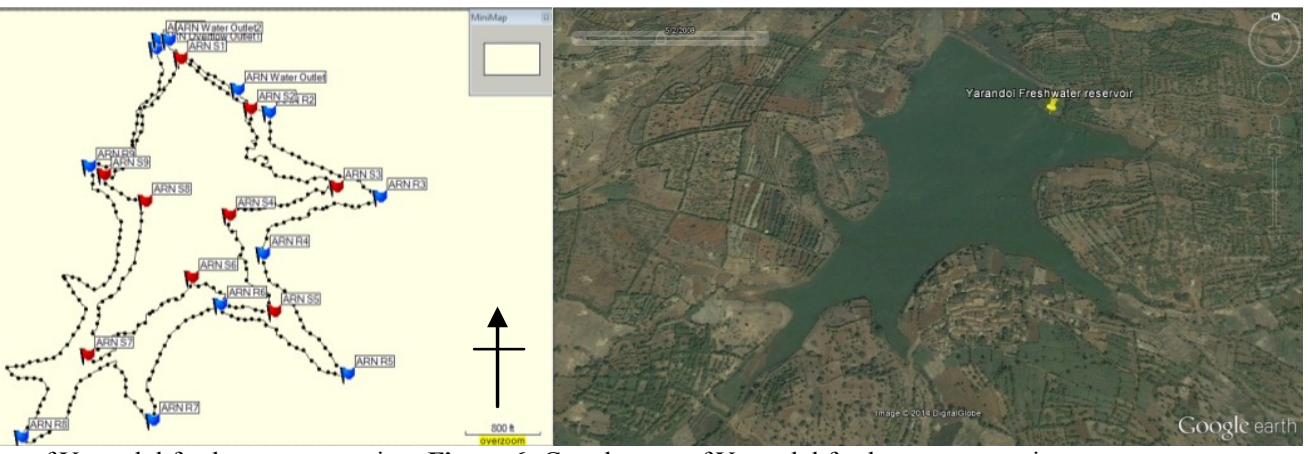

Figure 5: GPS map of Yarandol freshwater reservoir Figure 6: Google map of Yarandol freshwater reservoir

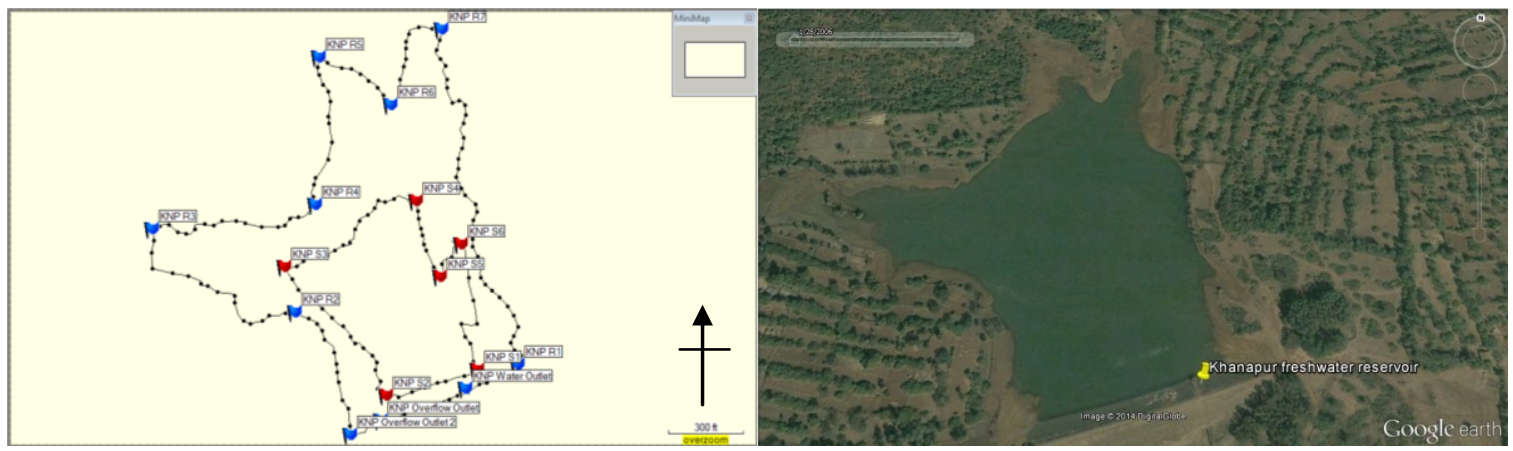

Figure 7: GPS map of Khanapur freshwater reservoir Figure 8: Google map of Khanapur freshwater reservoir
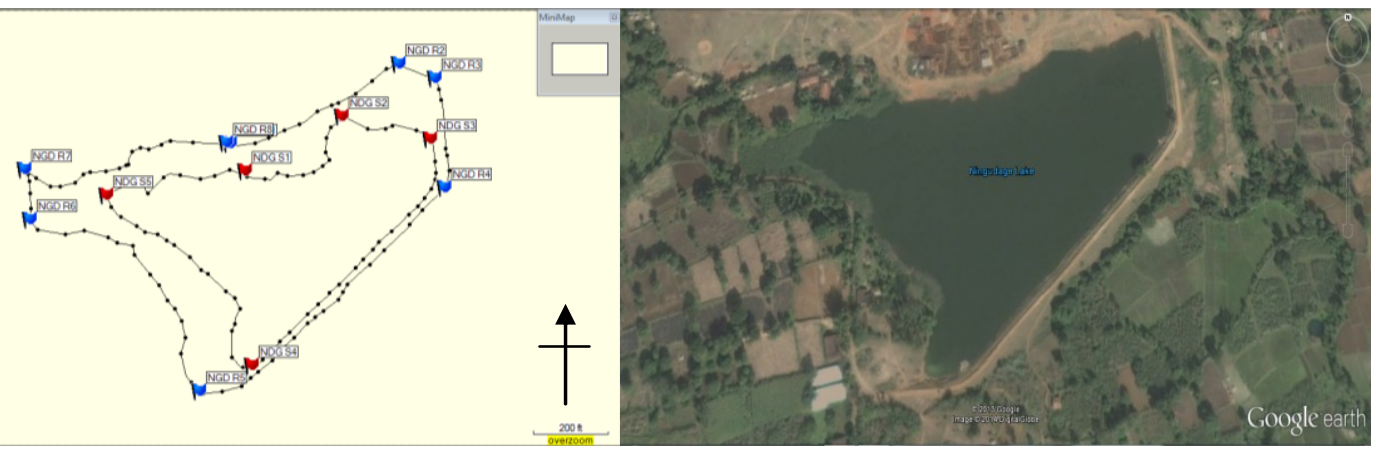

Figure9: GPS map of Ningudage freshwater reservoir Figure 10: Google map of Ningudage freshwater reservoir 
Status of freshwater bodies from Ajara tahsil of Kolhapur district (MS), India with special ....

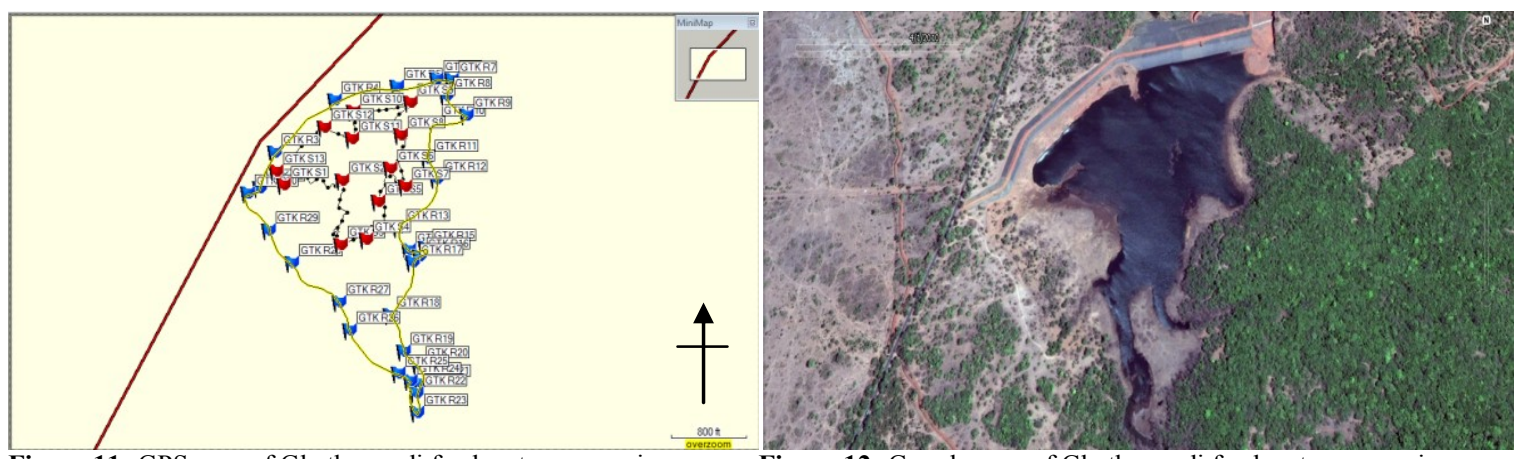

Figure 11: GPS map of Ghatkarwadi freshwater reservoir

Figure 12: Google map of Ghatkarwadi freshwater reservoir

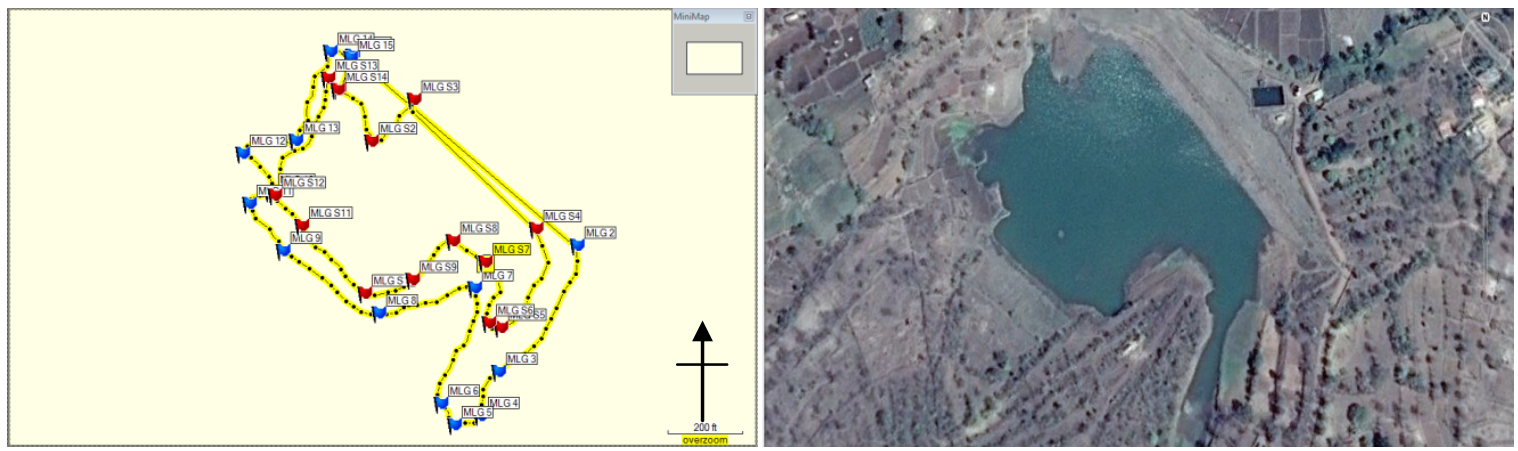

Figure 13: GPS map of Maligre freshwater reservoir Figure 14: Google map of Maligre freshwater reservoir

Note: Indicates boundry line of water during summer season

Indicates boundry line of water during monsoon season 